\title{
Transcatheter arterial embolisation of a haemorrhagic renal cyst
}

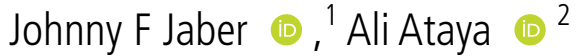

${ }^{1}$ Internal Medicine, University of Florida, Gainesville, Florida, USA 2Pulmonary, Critical Care, and Sleep Medicine, University of Florida, Gainesville, Florida, USA

\section{Correspondence to}

Dr Johnny F Jaber; jfjaber@gmail.com

\section{Accepted 15 June 2020}

\section{DESCRIPTION}

An 86-year-old woman with a history of orthotopic liver transplantation from non-alcoholic steatohepatitis, stage 4 chronic kidney disease secondary to calcineurin inhibitor toxicity and paroxysmal atrial fibrillation on apixaban presented to the emergency department with sudden right-sided abdominal pain radiating to the flank. She was initially hypotensive, tachycardic and responsive to intravenous fluids. Initial labs revealed a haemoglobin of $110 \mathrm{~g} / \mathrm{L}$ rapidly downtrending to $93 \mathrm{~g} / \mathrm{L}$, and a creatinine of $4.09 \mathrm{mg} / \mathrm{dL}$ up from her baseline of $2.46 \mathrm{mg} / \mathrm{dL}$. A CT scan of the abdomen and pelvis without contrast revealed a hyperdense right kidney with surrounding haemorrhagic fluid and stranding (figure 1). This patient had a history of bilateral simple renal cysts due to chronic kidney disease. As the patient had undergone no trauma, the patient presumptively had spontaneous haemorrhage into one of her simple renal cysts. Discussions were had with urologists and interventional radiologists, and the decision was made to proceed with angiography with possible embolisation. Angiography revealed multifocal areas of active haemorrhage identified in both the superior and the inferior poles of the right kidney (video 1). After multiple passes of

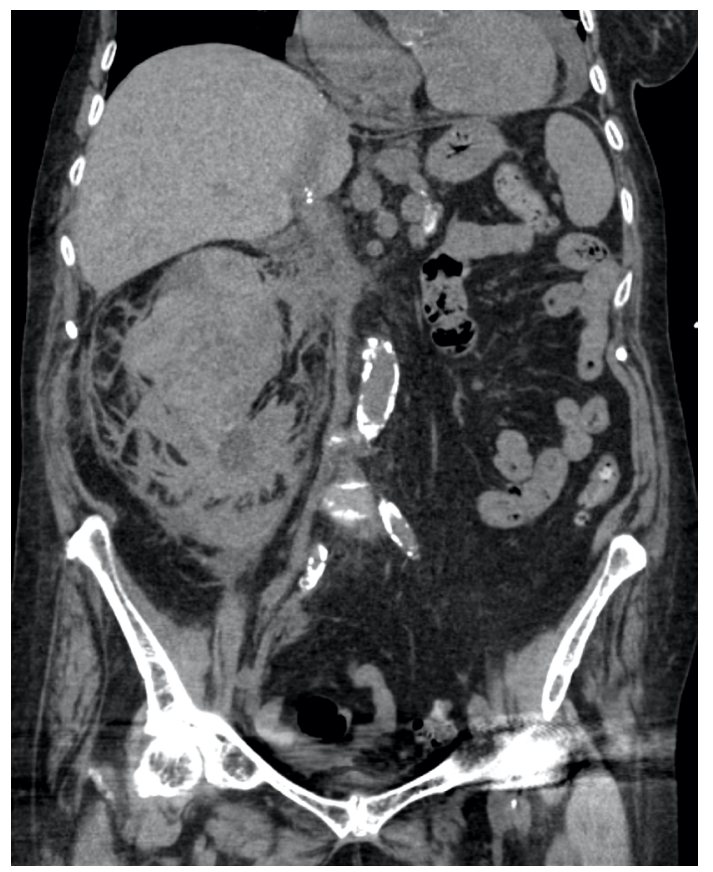

Figure 1 Coronal cross-section of a CT of the patient's abdomen without intravenous contrast demonstrating a hyperdense right kidney with surrounding haemorrhagic fluid and stranding.

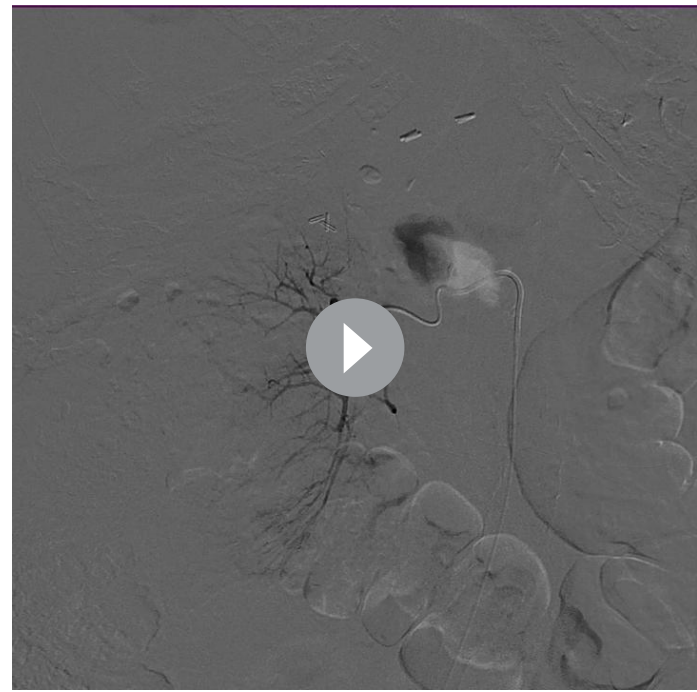

Video 1 Angiography of the patient's right renal artery demonstrating haemorrhage in the superior pole of the right kidney.

embolisation to the third-order branches of the right renal artery, approximately $70 \%-80 \%$ of the right renal artery was estimated to have been embolised. After embolisation, the patient's haemoglobin stabilised. She experienced persistent suprapubic and right flank pain, which resolved 48 hours postoperatively. She had an uneventful remainder of her stay in the hospital.

Haemodynamically significant renal haemorrhage is frequently seen in abdominal trauma, however not as commonly in those with a history of simple renal cysts. The gold standard of imaging is intravenous contrast-enhanced CT of the kidneys to evaluate the extent of haemorrhage. In the case of abdominal trauma, it is also the preferred imaging modality to stage the extent of renal injury and bleed. In patients who are deemed haemodynamically unstable, non-operative management of subcapsular and perirenal bleeding has been shown to be effective without the eventual need

\section{Learning points}

Though rare, both simple and complex renal cysts can be complicated by haemodynamically significant haemorrhage.

- Transcatheter arterial embolisation may be an appropriate non-operative option for the management of haemorrhage in those who are poor surgical candidates. 


\section{Images in...}

for operative management, including nephrectomy. ${ }^{1}$ There are scarce case reports in the literature discussing the treatment of intracystic bleeding with transcatheter arterial embolisation, as was done with this patient. ${ }^{2}$ Our patient's bleeding was well controlled with embolisation, which prevented the need to progress to surgery.

Contributors Both JFJ and AA participated equally in patient care, conceived the presented idea, and participated in writing the manuscript.

Funding The authors have not declared a specific grant for this research from any funding agency in the public, commercial or not-for-profit sectors.

Competing interests None declared.
Patient consent for publication Obtained.

Provenance and peer review Not commissioned; externally peer reviewed.

\section{ORCID iDs}

Johnny F Jaber http://orcid.org/0000-0002-7617-503X

Ali Ataya http://orcid.org/0000-0001-8505-1680

\section{REFERENCES}

1 Erlich T, Kitrey ND. Renal trauma: the current best practice. Ther Adv Urol 2018; 10:295-303.

2 Toriu N, Hoshino J, Kobori S, et al. Transcatheter arterial embolization therapy for huge renal cysts: two case reports. Case Rep Nephrol Dial 2018;8:82-9.

Copyright 2020 BMJ Publishing Group. All rights reserved. For permission to reuse any of this content visit

https://www.bmj.com/company/products-services/rights-and-licensing/permissions/

BMJ Case Report Fellows may re-use this article for personal use and teaching without any further permission.

Become a Fellow of BMJ Case Reports today and you can:

- Submit as many cases as you like

- Enjoy fast sympathetic peer review and rapid publication of accepted articles

- Access all the published articles

- Re-use any of the published material for personal use and teaching without further permission

\section{Customer Service}

If you have any further queries about your subscription, please contact our customer services team on +44 (0) 2071111105 or via email at support@bmj.com.

Visit casereports.bmj.com for more articles like this and to become a Fellow 